\title{
A quantitative case study assessment of biophysical and economic effects from altering season of calving in temperate pasture-based dairy systems
}

\author{
O. K. Spaans, ${ }^{1}$ K. A. Macdonald, ${ }^{1}$ M. Neal, ${ }^{1}$ M. J. Auldist, ${ }^{2}$ J. A. S. Lancaster, ${ }^{1}$ A. M. Bryant, ${ }^{1}$ G. J. Doole, ${ }^{1}$ \\ and J. R. Roche ${ }^{1,3 *} \dagger$ \\ ${ }^{1}$ DairyNZ, Private Bag 3221, Hamilton, New Zealand 3240 \\ ${ }^{2}$ Agriculture Victoria, 1301 Hazeldean Road, Ellinbank VIC 3821, Australia \\ ${ }^{3}$ School of Biological Sciences, University of Auckland, Private Bag 92019, Auckland 1142, New Zealand
}

\section{ABSTRACT}

In theory, a late winter-early spring calving date in temperate grazing systems best matches pasture supply and herd demand, thereby minimizing the need for nonpasture feeds and maximizing profitability. We used a quantitative case study approach to define the effects of season of calving on biophysical and financial performance in a grazing system without the confounding effects of imported feeds (i.e., milk production directly from grazed pasture). A 2-yr production system experiment was established to quantify the effects of changing onset of seasonal calving (i.e., planned start of calving; PSC) from winter (July in the Southern Hemisphere) to spring (October), summer, (January), or autumn (April) on pasture and animal production and profitability. Eighty Holstein-Friesian cows were randomly allocated to 1 of 4 PSC treatments, each of which had a different PSC [mean calving date of January 10 (JAN), April 10 (APR), July 10 (JUL), or October 10 (OCT)]. Data were analyzed for consistency of treatment response over years using ANOVA procedures with year, PSC treatment, and year $\times$ PSC treatment interactions as fixed effects. Collated biological data and financial data extracted from a national economic database were used as fixed variables to model the financial performance for the different treatments. A stochastic risk analysis was undertaken, where historical pasture growth and milk price data were used to estimate the probability distributions for stochastic input variables. Gross farm revenue and operating profit per hectare were modeled under 2 scenarios: (A) milk price did not include a premium for milk supplied during the winter, and (B) milk price included a realistic premium for milk supplied in winter. Annual and seasonal pasture growth did not

Received October 28, 2018.

Accepted July 25, 2019.

*Corresponding author: john.roche@mpi.govt.nz

$\dagger$ Current address: Ministry for Primary Industries, Pastoral House, Lambton Quay, Wellington 6011, New Zealand. differ between treatments, but the pasture growth $(\mathrm{kg}$ of dry matter/ha) and profile of the JUL treatment best matched the lactation nutrient demand profile. In comparison, profiles for JAN, APR, and OCT calving treatments had periods of greater surplus and deficit due to the time of calving and herd demand relative to the pasture growth profile. As a result, the JAN and OCT treatments conserved more pasture as silage and cows consumed a larger proportion of their annual diet as silage. Although the amount of silage conserved and consumed did not differ between the JUL and APR calving treatments, the timing of the silage consumption was different, with silage making up a greater proportion of the diets in the APR treatment 1 to 90 and 91 to $180 \mathrm{~d}$ postcalving and being offered to the JUL calving treatment only 271 to $365 \mathrm{~d}$ postcalving. As a result of differences in the quantity and proportion of pasture and pasture silage in the lactating diet, the JUL treatment herd tended to produce greater milk, $4 \%$ fat-corrected milk, fat, protein, and lactose yields $(\mathrm{kg} / \mathrm{cow})$ than the other PSC treatments, which did not differ from each other. Operating expenses per hectare did not differ materially between calving date scenarios, but operating expenses per kilogram of fatcorrected milk and kilogram of fat and protein were 15 to $20 \%$ less in the JUL treatment. With or without a realistic winter milk premium, gross farm revenue and operating profit per hectare were greater in the JUL treatment than in the APR treatment, which had greater revenue and profitability than the remaining 2 calving date treatments. In summary, our results indicate that a PSC in late winter is most profitable in a grazing system not importing feed, with or without a realistic price incentive scheme.

Key words: robustness, seasonal calving, grazing, financial performance

\section{INTRODUCTION}

In temperate regions, the cost of milk produced from pasture is low, whereas the milk produced from im- 
ported (i.e., supplemental) feeds can have a high marginal cost (Dillon et al., 2005; Macdonald et al., 2017). Therefore, a key aim of profitable grazing systems is to maximize the amount of milk produced directly from pasture (Roche et al., 2017). Temporal pasture growth rates vary throughout the year, with peak growth during spring (Roche et al., 2009b). Therefore, traditionally, pasture-based herds are managed such that the planned start of seasonal calving (PSC) is mid to late winter to ensure that the high nutrient demand at peak lactation $(\sim 80 \mathrm{DIM})$ coincides with seasonal peaks in pasture yield and digestibility in spring (Roche et al., $2009 \mathrm{~b}$ ) and that the lowest nutrient demand (i.e., the nonlactating period) coincides with lowest pasture yield in winter (Dillon et al., 1995; McCarthy et al., 2012).

Fluid milk markets, however, require a daily supply of fresh milk, even during winter, and the return on investment for milk processors is negatively affected by a pronounced peak-to-trough annual supply profile (Davis and Kirk, 1984; Keane, 2010). Therefore, many milk purchasers offer a premium for milk produced outside the traditional winter calving supply period. Changing the calving season can result in a mismatch between the profiles of pasture availability and herd feed requirements throughout the year (García and Holmes, 2005), thereby introducing the potential for nutritional deficits at key times, pasture surplus to requirements at others, and a greater requirement for conservation (i.e., silage or hay) or supplemental feed (Funston et al., 2016). All of these factors have the potential to affect gross farm revenue or operating expenses or both and, thereby, farm profitability (García et al., 2000).

Our objective was to determine the biophysical and economic effects of altering season of calving in a compact, seasonal, pasture-based dairy production system. We used a quantitative case study approach to determine the effect of changing the PSC on pasture production and utilization, milk production, gross farm revenue and expenses, and operating profit in a system not importing feed from off-farm. Additionally, a Monte Carlo simulation using @Risk software (Palisade, 2017) was completed to assess the relative risks associated with milk price and production inputs on farm economic performance for each calving date scenario.

\section{MATERIALS AND METHODS}

The experiment was conducted over 2 lactations at No. 2 Dairy Farm, DairyNZ, Hamilton, New Zealand $\left(37^{\circ} 47^{\prime} \mathrm{S}, 175^{\circ} 19^{\prime} \mathrm{E}, 40 \mathrm{~m}\right.$ above sea level). The permanent grassland area had pastures of predominantly ryegrass (Lolium perenne L.) and white clover (Trifolium repens L.) with an evenly distributed soil type- specifically, a Te Rapa peaty silt loam soil, known as a Humic Aquic Haplorthod in soil taxonomy or a Humose Groundwater-Gley Podzol in the New Zealand classification.

\section{Experimental Design and Treatments}

Eighty Holstein-Friesian cows were randomly allocated into 4 herds of 20 cows each, which were then randomly assigned to 1 of 4 future PSC treatments: PSC in summer on January 10 (JAN), in autumn on April 10 (APR), in winter on July 10 (JUL), or in spring on October 10 (OCT). The herds were established during the 3 yr before beginning the study.

Sixty-four paddocks (defined grazing area of 0.405 ha/paddock) were randomly allocated to 1 of the 4 PSC treatment farmlets (6.7 ha and 16 paddocks/ treatment), ensuring that each farmlet was represented equally for soil type, previous pasture growth (DM/ ha), and distance from the milking parlor; these treatment farmlets remained unchanged throughout the experiment. The 16 paddocks were further subdivided, as necessary, through the use of temporary electric fences (Roche et al., 2017). Stocking rate was the same for all treatments at 3 cows/ha.

\section{Experiment Management}

Grazing and Fertilizer Management. Grazing management was determined by monitoring farm pasture cover on a weekly basis. Each herd was allocated fresh pasture once daily and, as described by Macdonald et al. (2008), returned to the same area only when a minimum of 2 leaves were present on the majority $(>66 \%)$ of perennial ryegrass tillers, thus determining the rotation lengths of the farmlets. For the JAN, APR, JUL, and OCT PSC treatments, respectively, the average number of days in the rotation length was as follows: winter: $56 \pm 2.7,62 \pm 13.4,77 \pm 12.7$, and 56 \pm 7.2 ; spring: $22 \pm 5.0,23 \pm 5.0,22 \pm 5.6$, and $41 \pm$ 16.3; summer: $47 \pm 20.3,24 \pm 5.0,24 \pm 2.0$, and $26 \pm$ 5.1; autumn: $38 \pm 7.6,50 \pm 9.3,34 \pm 9.9$, and $33 \pm 9.3$. Surplus pasture was conserved as silage when growth rate exceeded herd DMI.

Pasture was sampled for DM content before being conserved as silage in bales; the bales were weighed from each paddock to give an estimate of the amount of feed conserved. Mechanical cutting (i.e., topping or clipping) of residual pasture postgrazing was applied as deemed necessary to maintain quality. All treatments received annual maintenance top-dressings with $54 \mathrm{~kg}$ of $\mathrm{P} / \mathrm{ha}$ and $55 \mathrm{~kg}$ of $\mathrm{S} / \mathrm{ha}$ (as single superphosphate), $50 \mathrm{~kg}$ of $\mathrm{K} / \mathrm{ha}$ (as muriate of potash), and $150 \mathrm{~kg}$ of N/ 
ha for the maintenance of nutrient levels. If silage was made, an additional $50 \mathrm{~kg}$ of $\mathrm{K} /$ ha was applied to the area postharvesting.

Cow Management. Each treatment was managed individually according to the stage of lactation of the herd; however, each stage was managed similarly across the treatments. Mating management policy was to identify cows exhibiting estrus behavior before the planned start of the seasonal breeding period (PSB) and mark them with tail paint: PSB for the January calving treatment was April, for the April calving treatment was July, for the July calving treatment was October, and for the October calving treatment was January. By PSB, cows that were not displaying signs of estrus underwent a veterinary examination and, if lacking a palpable corpus luteum, were treated with an intravaginal controlled internal drug-releasing insert (InterAg, Hamilton, New Zealand) following the Genermate program (Cliff et al., 1995). Artificial insemination was performed for the first 6 wk from PSB, with a further $5 \mathrm{wk}$ of natural breeding to follow. Manual palpation of the uterine contents diagnosed positive pregnancy, occurring at least $5 \mathrm{wk}$ after the end of the breeding period.

Cows to be culled were removed at a rate of $20 \%$ each lactation based on reproductive failure, age, health, or genetic merit and were replaced with primiparous cows before PSC. As described by Macdonald and Penno (1998), lactation lengths of individual cows were shortened based on BCS relative to calving targets (Roche et al., 2009a), production yields, and number of days to the next calving.

Cow Health. Because the pasture had low Mg and relatively high $\mathrm{K}$ and $\mathrm{N}$ concentrations during winter and spring, $\mathrm{Mg}$ supplements were routinely administered during this period to all treatments to prevent hypomagnesemia and associated hypocalcemia (Macdonald et al., 2008, 2017). Magnesium was provided in the form of magnesium oxide top-dressed daily across all pastures grazed by nonlactating cows from $3 \mathrm{wk}$ before the planned start of calving until calving. After calving, all lactating cows received an oral supplement of magnesium chloride, containing $20 \mathrm{~g}$ of elemental $\mathrm{Mg}$, at their morning milking for approximately $4 \mathrm{mo}$ postcalving. During periods of increased risk of bloating, cows were drenched with an antibloating solution at their morning milking and, similarly, given zinc sulfate orally at a rate of $3.6 \mathrm{~g} / 100 \mathrm{~kg}$ of BW during increased fungal (Pithomyces chartarum) spore counts, which indicate increased vulnerability to facial eczema. Mastitis and udder health were monitored using SCC from weekly herd-test data, and any infections or abnormalities were treated appropriately. Troughs were provided in every paddock for the cows to access drinking water.

\section{Measurements}

Pasture Measurement. A weekly farm walk was completed by the same assessor throughout the experiment to visually assess pasture DM per hectare in each paddock using a method similar to that outlined by O'Donovan et al. (2002). Pasture within 11 calibration quadrats $\left(0.3 \mathrm{~m}^{2}\right)$, representing the range of pasture mass present on the farm, was cut to ground level after the visual assessment and then washed and dried in a forced-draft oven at $100^{\circ} \mathrm{C}$ until dry $(\sim 48 \mathrm{~h})$. Using a regression of quadrat visual assessment on measured quadrat pasture mass, the visual pasture mass estimate for each paddock was adjusted. The net pasture accumulation ( $\mathrm{kg}$ of $\mathrm{DM} / \mathrm{ha}$ ) was calculated weekly from the pasture mass increase in paddocks left ungrazed. The net pasture accumulation each week (i.e., a proxy for pasture grown) for 52 wk was summed to provide annual and seasonal pasture growth for each paddock.

$D M I$. Throughout the trial, 1 person visually assessed pasture mass pre- and postgrazing in individual paddocks on $3 \mathrm{~d}$ each week. Weekly average herd DMI ( $\mathrm{kg}$ of DM/ha) was calculated from the difference between pre- and postgrazing mass, with cow DMI calculated as the herd DMI divided by the number of cows in each treatment herd.

Milk, $B C S$, and $B W$. Milk yield and composition were measured twice weekly during consecutive p.m. and a.m. milkings (Tru-Test milk meter system, Palmerston North, New Zealand), and milk fat, CP, TP, casein, and lactose concentrations were determined by aliquot samples using a Fossomatic FT120 (Foss Electric, Hillerød, Denmark). The milk component data were verified by reference techniques for a subset of milk samples as described in Macdonald et al. (2008).

The BW and BCS of each cow were measured every second week following the morning milking, or at 0900 $\mathrm{h}$ during the nonlactating period, for the duration of the experiment. Body condition score was assessed on a 10 -point scale, where 1 is emaciated and 10 is obese (Roche et al., 2004). Calving BW and calf birth weight were recorded within $18 \mathrm{~h}$ of calving.

\section{Statistical Analyses and Economic Modeling}

Data were analyzed for consistency of PSC treatment response over 2 yr by calculating means for each variable for each treatment in each year and analyzing these using ANOVA procedures in Genstat (Genstat VSNi, Hempstead, United Kingdom), with year, PSC 
treatment, and year $\times$ PSC treatment interactions as fixed effects. A $P$-value of $<0.05$ was considered statistically significant.

For the purposes of comparing lactation stages, regardless of PSC, the data from each treatment group were divided into early lactation (1-90 d postcalving), early to mid lactation (91-180 d postcalving), mid to late lactation (181-270 d postcalving), late lactation (>270 d postcalving), and the nonlactating period (271-365 d postcalving) to compare stages of lactation for the PSC treatments. Production data were averaged across years to provide 1 value per treatment for each lactation stage, and the data were statistically analyzed as described previously. The percentage of stock replaced each year (20\%) was the same across treatments.

Base Economic Model. The economics of the calving date treatments were modeled to give a base economic model using the same methodology described by Macdonald et al. (2011, 2017), where the proportion of each expense category was classified as a per-cow or per-hectare expense; the proportions are presented in Supplemental Table S1 (https://doi.org/10.3168/jds .2018-15911). All dollar values presented are in NZ\$ unless otherwise specified; NZ\$1 $=$ US $\$ 0.66$ and $€ 0.59$ at the time of writing.

Wherever expenses could be separated for individual treatments (e.g., feed, silage conservation), actual data were used. Wherever data could not be separated for individual treatments because of the structure of the research farm accounting system (administration, depreciation, electricity costs, repairs and maintenance, standing charges, vehicle expenses), equivalent expenses per cow and per hectare from similar farming systems were extracted from a commercial database used for measuring and benchmarking farm economic performance in New Zealand (DairyBase, DairyNZ, Hamilton, New Zealand; Supplemental Table S2, https: //doi.org/10.3168/jds.2018-15911; n $=87$ farms over 3 yr: 2012-2015).

Changes in the month of onset of calving affected the volume of effluent collected in effluent ponds due to the time of year peak effluent volume coincided with peak rainfall. Therefore, the size of the pond required for the treatment differed. Due to the increased size of the effluent pond required for effective management relative to the JUL treatment, the installation and subsequent depreciation for each pond was greater. Effluent pond calculations are presented in Supplemental Table S3 (https://doi.org/10.3168/jds.2018-15911).

The base economic model (Supplemental Table S1, https://doi.org/10.3168/jds.2018-15911) was calculated using fixed estimated mean values for the input variables, which were as follows: $\$ 250 / \mathrm{t}$ of DM to pur- chase silage, $\$ 150 / \mathrm{t}$ of DM to sell silage, $\$ 100 / \mathrm{t}$ of $\mathrm{DM}$ to make silage, and $\$ 500 / \mathrm{t}$ of urea. The farmlets were managed individually in terms of silage made, sold, and bought so that silage made on one treatment could be fed back only to the herd on the same treatment, and any excess silage was sold. Carcass weight payment $(\$ /$ $\mathrm{kg}$ ) varied by month of sale (January $=\$ 2.92$, February $=\$ 2.96$, March $=\$ 2.98$, April $=\$ 2.94$, May $=\$ 2.96$, June $=\$ 3.14$, July $=\$ 3.25$, August $=\$ 3.34$, September $=\$ 3.35$, October $=\$ 3.19$, November $=\$ 3.08$, and December $=\$ 3.03)$. Milk price was calculated individually for each treatment because under a component-pricing market the values per kilogram of fat and protein are different, and a premium for milk supplied during the winter period of May 16 to July 15 was also included (calculations are given in Supplemental Table S4, https: //doi.org/10.3168/jds.2018-15911). The milk price was calculated using the Fonterra Ltd. (Auckland, New Zealand) 2017-2018 milk price schedule, as previously published by Chikazhe et al. (2017), and included the base price for milk, a premium for out-of-season milk, and a volume adjustment penalty for milk produced during the period of peak processing (i.e., spring; details are presented in Supplemental Table S4 and Supplemental File S1, https://doi.org/10.3168/jds.2018-15911). Base milk price was as follows: milk fat $=\$ 4.05 / \mathrm{kg}$; milk protein $=\$ 8.10 / \mathrm{kg}$ for both peak and nonpeak months. Winter premiums were $+\$ 2.85 / \mathrm{kg}$ of fat and protein produced during May 16 to $31,+\$ 3.50 / \mathrm{kg}$ of fat and protein produced during June 1 to $15,+\$ 3.50 / \mathrm{kg}$ of fat and protein produced during June 16 to 30 , and $+\$ 2.85 / \mathrm{kg}$ of fat and protein produced during July 1 to 15 . The standardized milk price received without the winter premium was $\$ 6.16 / \mathrm{kg}$ of fat and protein. The milk price $(\$ / \mathrm{kg}$ of fat and protein) received with the winter premium and peak volume adjustment included was $\$ 6.60$ for the JAN treatment, $\$ 6.60$ for the APR treatment, $\$ 5.97$ for the JUL treatment, and $\$ 6.54$ for the OCT treatment.

Risk Modeling. The base economic model (Supplemental Table S1, https://doi.org/10.3168/jds.2018 -15911) was used to assess the risk to profit of the alternative calving date treatments in the current experiment using @Risk software (Palisade, 2017), a Microsoft Excel plug-in. @Risk (Palisade, 2017) allows a distribution for input variables to be specified to perform a Monte Carlo simulation analysis of an output variable (Hardaker et al., 2015). Single estimates of the variables of interest - specifically, the mean values for milk price, silage cost, urea price, meat price, and annual pasture yield - were replaced with distributions for each variable (Figure 1 ).

A milk price data set of mean annual milk price for the last $15 \mathrm{yr}$ was well represented by an extended 
value distribution, with a mean $( \pm \mathrm{SD})$ of $\$ 6.16 \pm$ $1.54 / \mathrm{kg}$ of fat and protein. The variable silage cost, determined from national data for similar supplements, was fitted with a Weibull distribution (mean $=\$ 290 \pm$ $47 / \mathrm{t}$ DM. The distribution for the urea price variable was obtained from Neal and Cooper (2016), who fitted
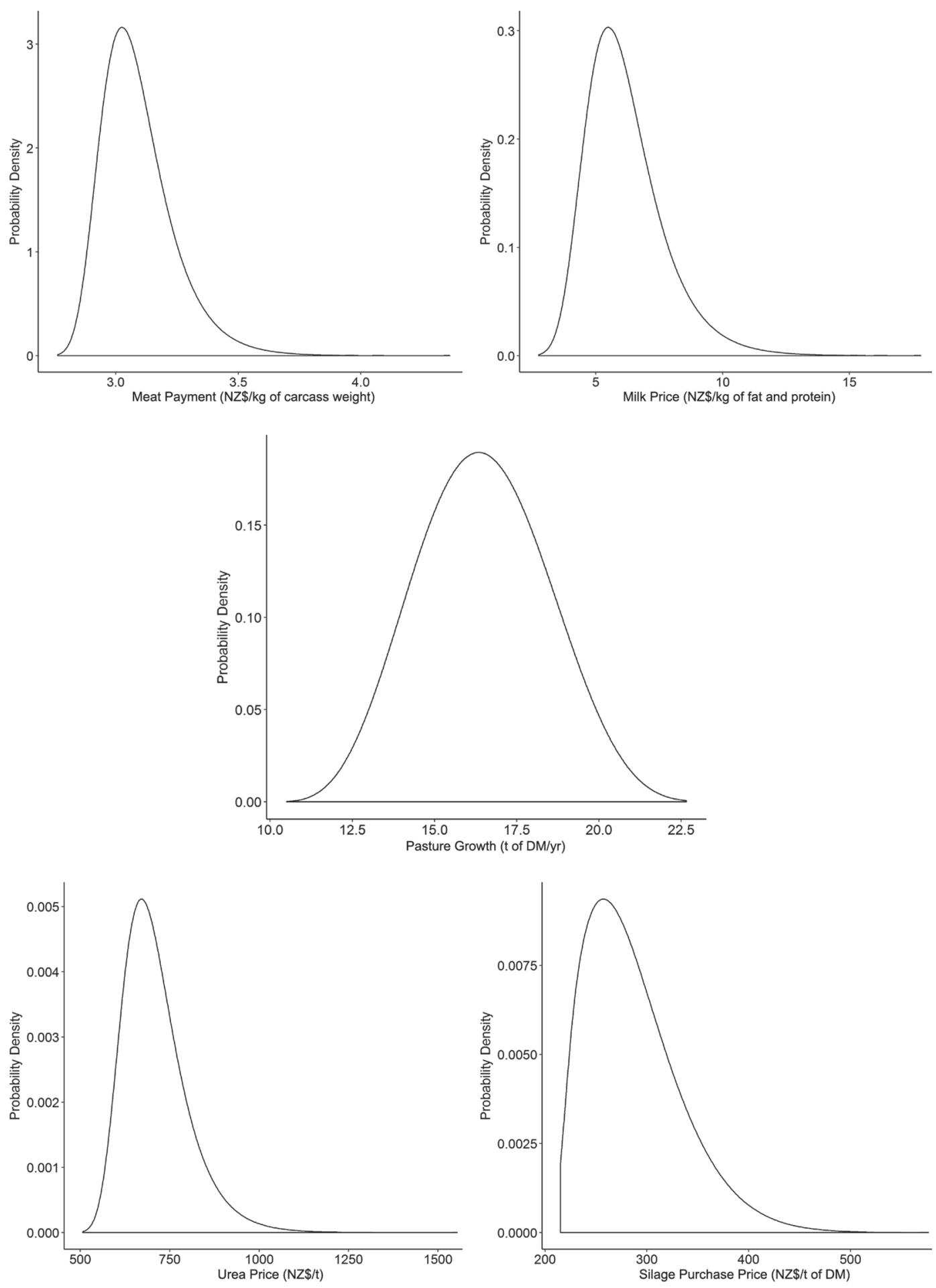

Figure 1. Probability density distributions for value/cost of input variables: meat payment (distribution mean $\pm \mathrm{SD}: \mathrm{NZ} \$ 3.09 \pm 0.15 / \mathrm{kg}$ of carcass weight), milk price (distribution mean: $\mathrm{NZ} \$ 6.16 \pm 1.54 / \mathrm{kg}$ of fat and protein), annual pasture growth (distribution mean: $16.5 \pm 2.0$ $\mathrm{t}$ of $\mathrm{DM} / \mathrm{yr}$ ), urea price (distribution mean: NZ $\$ 711.01 \pm 91.09 / \mathrm{t}$ ), and silage purchase cost (distribution mean: $\mathrm{NZ} \$ 286.69 \pm 46.84 / \mathrm{t}$ of $\mathrm{DM}$ ). Values were calculated using @Risk software (Palisade, 2017) and graphed using R software (R Core Team, 2013). 
an extended value distribution ( mean $=\$ 711 \pm 91 / \mathrm{t}$ ) . The data set for meat payment was the last $10 \mathrm{yr}$ of payment for kilogram of carcass weight, obtained from Beef and Lamb NZ (Wellington, New Zealand, personal communication). The data, after adjusting for fixed effect of month, was well represented by an extended value distribution $($ mean $=\$ 3.09 \pm 0.15 / \mathrm{kg})$. The data set for the annual pasture growth variable was the annual pasture growth for No. 2 Dairy and Scott farm (DairyNZ research farms) for the last $20 \mathrm{yr}$, which was well represented by a $\beta$ general distribution (mean $=$ $16.5 \pm 2.0 \mathrm{t}$ of $\mathrm{DM})$.

Correlations between variables were also included in the analysis and were 0.1 for milk price and urea price, -0.3 for annual pasture yield and milk price, and 0.1 for urea price and annual pasture yield (Neal and Cooper, 2016). Output variables for the model are dairy operating expenses $(\$ /$ ha), gross farm revenue $(\$ /$ ha), and operating profit (\$/ha). Using @Risk (Palisade, 2017), Monte Carlo simulations were then performed with 10,000 iterations to generate probability density functions for the outputs for each treatment: dairy operating expenses, gross farm revenue, and dairy operating profit under both the base scenario of no premium included and the alternative scenario of a premium for winter milk included. Monte Carlo techniques yielded a probability distribution for each model output, conditional on the joint distribution of all input data. This probability density function was then transformed into a cumulative density function (CDF), which represented the likelihood of the potential outcomes occurring.

\section{RESULTS AND DISCUSSION}

Traditionally, it has been assumed that operating profit is maximized by establishing the PSC during winter, such that the peak DMI of the herd coincides with peak growth of highest digestibility pasture, reducing the need for imported supplements and the increased cost of marginal milk associated with that strategy (Roche et al., 2009b, 2017; Macdonald et al., 2017; Roche, 2017). However, very few studies have evaluated this assumption, and none have ensured that stocking rate was identical under the different calving date treatments. Furthermore, although biophysical changes associated with changing PSC from late winter to autumn have been reported, the profitability of both options has not been considered in a nutritionally unconfounded comparison, nor has the risk to profitability from altering season of calving when relevant changes in pasture growth, milk price, and input prices have been evaluated. We had a unique opportunity to establish a platform to compare 4 alternative calving seasons using a quantitative case study approach to evaluate the econometric performance of altering calving date in a temperate pasture-based dairy system.

\section{Diet Composition and Milk Production}

Effects of month of calving on pasture growth, the amount of pasture conserved as silage, and pasture, supplement, and total DMI are presented in Table 1. Annual pasture growth ( $\mathrm{kg}$ of DM/ha) was not affected by season of calving, but the profile of herd feed demand (i.e., stage of lactation) relative to the pasture production profile was clearly affected by treatment. This meant that the proportion of fresh pasture versus pasture silage present in the diet at the different stages of lactation differed with calving date treatment. For example, cows in the APR calving treatment had the least pasture available to them during 1 to $90 \mathrm{~d}$ postcalving, the period of greatest herd feed requirements, but most feed available to them 181 to $270 \mathrm{~d}$ postcalving. Furthermore, the occurrence of peak pasture growth at 181 to $270 \mathrm{~d}$ postcalving ensured that the cows in the APR calving treatment had a longer lactation than cows in the JUL calving treatment, where 181 to $270 \mathrm{~d}$ postcalving coincided with the summer period and low pasture growth relative to demand.

García and Holmes (2005) suggested that similar levels of pasture production and utilization can be achieved in contrasting pasture-based calving systems if common grazing, conservation, and feeding management criteria are applied to all systems. Our results support this position because treatment did not significantly affect annual pasture DM yield per hectare or the combination of pasture harvested per hectare directly and as silage $(P=0.32)$. However, diet composition during the different stages of lactation was affected by treatment $(P<0.05)$, and this tended $(P<0.1)$ to have a material effect on the milk production of the cows. This difference in diet composition at the different stages of lactation is evident in Table 1 and Figure 2. This is the most likely reason for the trend for lower milk production in the JAN, APR, and OCT treatments compared with the JUL calving treatment despite the longer lactations in the JAN and APR PSC treatments (Table 2), as conserved feeds are inferior in digestibility and AA composition to fresh pasture in spring, the sole diet of the JUL calving treatment (Dillon et al., 2002).

The tendency $(P<0.1)$ for a treatment effect on milk production variables reflects a trend for Julycalving cows to produce more milk than cows in the other 3 PSC treatments. However, this is not consistent with previous work in temperate grazing systems. García et al. (2000) reported that autumn-calving cows produced $52 \mathrm{~kg}$ more milk fat and protein compared with spring-calving cows and claimed that the greater 
Table 1. Effect of change in month of onset of calving in a seasonal calving system on pasture growth; pasture, supplement, and total DMI; and pasture conserved as silage

\begin{tabular}{|c|c|c|c|c|c|c|}
\hline \multirow[b]{2}{*}{ Item } & \multicolumn{4}{|c|}{ Onset of calving $^{1}$} & \multirow[b]{2}{*}{$\mathrm{SED}^{2}$} & \multirow[b]{2}{*}{$P$-value } \\
\hline & JAN & APR & JUL & OCT & & \\
\hline \multicolumn{7}{|l|}{ Pasture growth (kg of DM/ha) } \\
\hline Early lactation 3 & $4,357^{\mathrm{b}}$ & $1,238^{\mathrm{c}}$ & $3,311^{\mathrm{bd}}$ & $6,818^{\mathrm{a}}$ & 574.4 & $<0.01$ \\
\hline Early to mid lactation ${ }^{4}$ & $1,325^{\mathrm{c}}$ & $3,500^{\text {bd }}$ & $7,894^{\mathrm{a}}$ & $4,870^{\mathrm{b}}$ & 765.2 & $<0.05$ \\
\hline Mid to late lactation 5 & $3,834^{\mathrm{bc}}$ & $8,254^{\mathrm{a}}$ & $5,583^{\mathrm{ac}}$ & $1,661^{\mathrm{b}}$ & 870.9 & $<0.05$ \\
\hline Late lactation $^{6}$ & $7,873^{\mathrm{a}}$ & $4,774^{\mathrm{abc}}$ & $2,538^{\mathrm{c}}$ & $3,392^{\mathrm{bc}}$ & 973.0 & $<0.05$ \\
\hline Annual growth & 17,389 & 17,767 & 19,327 & 16,741 & $1,463.1$ & 0.46 \\
\hline \multicolumn{7}{|l|}{ Pasture DMI (kg of DM/cow per day) } \\
\hline Early lactation & 11 & 9 & 10 & 11 & 1.1 & 0.31 \\
\hline Early to mid lactation & $9^{\mathrm{b}}$ & $10^{\mathrm{b}}$ & $15^{\mathrm{a}}$ & $14^{\mathrm{a}}$ & 0.7 & $<0.01$ \\
\hline Mid to late lactation & $10^{\mathrm{bc}}$ & $15^{\mathrm{ab}}$ & $15^{\mathrm{a}}$ & $10^{\mathrm{c}}$ & 1.2 & $<0.05$ \\
\hline Late lactation & 14 & 14 & 11 & 12 & 1.4 & 0.17 \\
\hline Annual intake (kg of DM/cow) & 4,073 & 4,306 & 4,679 & 4,205 & 256.6 & 0.28 \\
\hline \multicolumn{7}{|l|}{ Supplement (kg of DM/cow per day) } \\
\hline Early lactation & 0 & 1 & 0 & 0 & 0.2 & 0.09 \\
\hline Early to mid lactation & 4 & 3 & 0 & 1 & 1.3 & 0.16 \\
\hline Mid to late lactation & 4 & 0 & 0 & 5 & 1.6 & 0.12 \\
\hline Late lactation & 0 & 0 & 3 & 2 & 1.3 & 0.19 \\
\hline Annual intake (kg of DM/cow) & 699 & 371 & 348 & 700 & 121.5 & 0.10 \\
\hline Annual conservation ( $\mathrm{kg}$ of $\mathrm{DM} / \mathrm{ha}$ ) & $1,965^{\mathrm{a}}$ & $1,158^{\mathrm{ac}}$ & $1,247^{\mathrm{b}}$ & $2,029^{\mathrm{bc}}$ & 216.8 & 0.05 \\
\hline \multicolumn{7}{|l|}{ Total DMI (kg of DM/cow per day) } \\
\hline Early lactation & 11 & 10 & 10 & 11 & 1.1 & 0.53 \\
\hline Early to mid lactation & 13 & 13 & 15 & 15 & 0.8 & 0.12 \\
\hline Mid to late lactation & 14 & 15 & 15 & 15 & 0.9 & 0.63 \\
\hline Late lactation & 14 & 14 & 14 & 13 & 0.8 & 0.64 \\
\hline Annual intake (kg of DM/cow) & 4,772 & 4,677 & 5,026 & 4,905 & 160.4 & 0.32 \\
\hline
\end{tabular}

${ }^{\mathrm{a}-\mathrm{d}}$ Means with different superscripts differ significantly $(P<0.05)$.

${ }^{1} \mathrm{JAN}=$ planned calving date of January 10; APR = planned calving date of April 10; JUL = planned calving date of July 10; OCT = planned calving date of October 10.

${ }^{2}$ Standard error of the difference.

${ }^{3}$ Early: JAN = December, January, February; APR = March, April, May; JUL $=$ June, July, August; OCT $=$ September, October, November.

${ }^{4}$ Early to mid: JAN = March, April, May; APR = June, July, August; JUL = September, October, November; OCT $=$ December, January, February.

${ }^{5} \mathrm{Mid}$ to late: JAN = June, July, August; APR = September, October, November; JUL = December, January, February; OCT $=$ March, April, May.

${ }^{6}$ Late: JAN = September, October, November; APR = December, January, February; JUL = March, April, May; OCT = June, July, August.

production was due to a 50-d-longer lactation (291 vs. $241 \mathrm{~d})$. However, their design was confounded, as the autumn calving treatment had a lower stocking rate ( 2.0 vs. 2.4 cows/ha). As a result, autumn-calving cows had a greater feed allocation, which would be expected to increase milk production per cow, and milk production per hectare was not affected by calving date. Furthermore, diet composition was different between treatments: autumn-calving cows received 79, 10, 10, and $1 \%$ of their diet from pasture, corn silage, pasture silage, and hay, respectively, whereas spring-calving cows received $80,0,15$, and $5 \%$ of their diet from these respective feed ingredients. Any or, more likely, all of these confounding features would have affected milk production per cow; therefore, it is not appropriate to report the differences as a result of calving date. For example, regression equations derived from Macdonald et al. (2008) predicted that the reduction in stocking rate alone would increase the per-cow yield of fat and protein by 20 to $25 \mathrm{~kg}$. When only calving date was changed, our results indicate a trend for greater milk production per cow and, by extension, per hectare in JUL cows compared with cows in the APR, OCT, or JAN PSC treatments.

\section{$B W$ and BCS}

The pre- and postcalving BW, BCS, and calf birth weights for each treatment are presented in Table 2 . Changing the month of calving affected precalving BW, with APR cows being lighter than cows in the other 3 treatments, which did not differ from each other. In comparison, precalving BCS was not affected by calving date treatments, with calving targets achieved in each scenario (Roche et al., 2009a). However, BCS immediately postcalving was affected by treatment, re- 

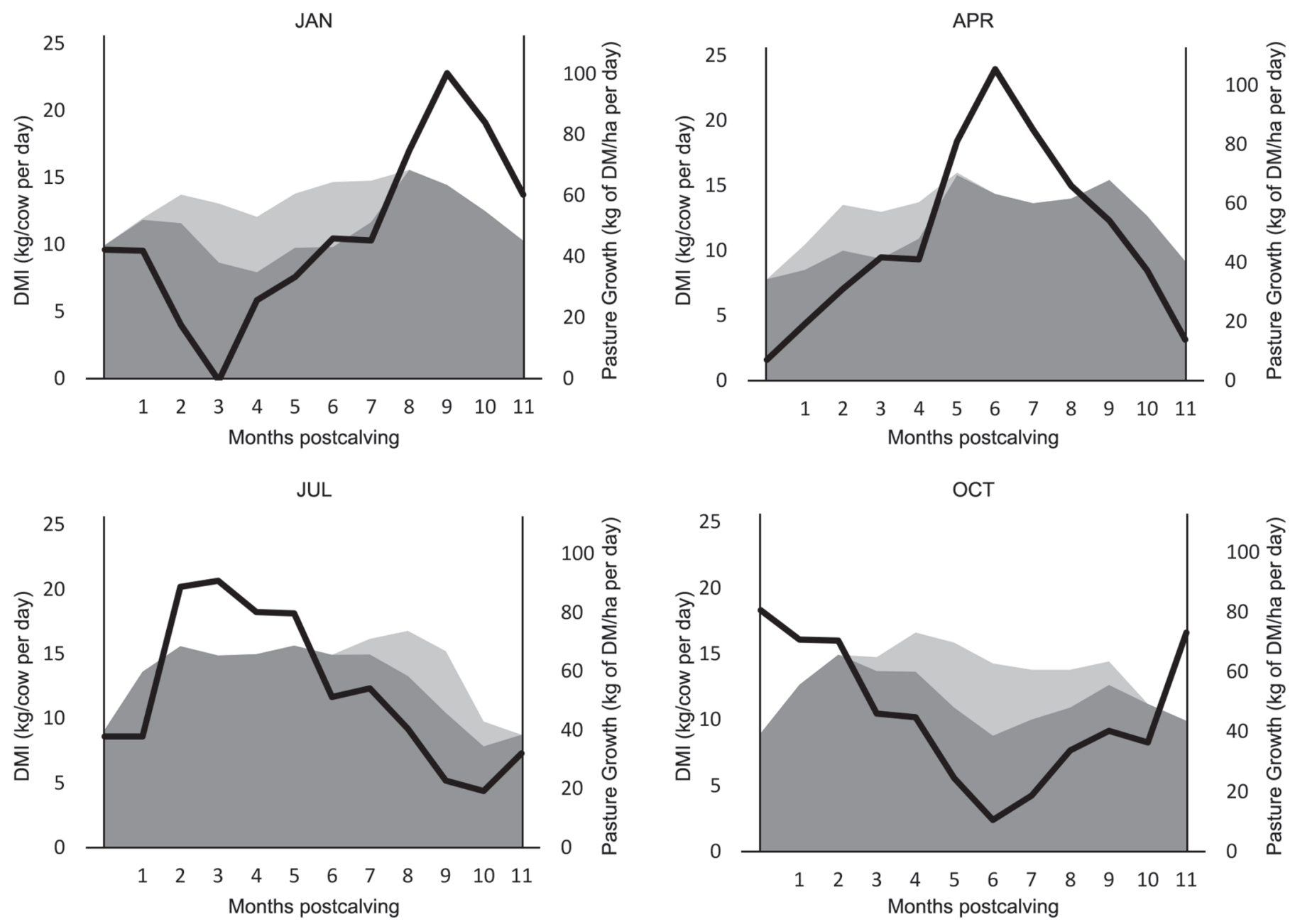

Figure 2. Effect of change in month of onset of calving on pasture (dark gray area) and supplement (light gray area) daily DMI to give a total daily DMI (total gray area; $\mathrm{kg}$ of $\mathrm{DM} /$ cow per day) relative to pasture growth (black line; $\mathrm{kg}$ of $\mathrm{DM} /$ ha per day). JAN = planned calving date of January 10; APR = planned calving date of April 10; JUL = planned calving date of July 10; OCT = planned calving date of October 10.

flecting differences in the amount of body condition lost between 1 mo precalving and 1 wk postcalving. Cows in the APR treatment had the greatest negative change in BCS during the transition period, probably reflecting a diet that was less energy and AA dense because of the greater amount of pasture silage in their diet immediately postcalving (Roche et al., 2005; Mandok et al., 2014). In comparison, the JUL- and OCT-calving cows lost the least body condition, probably a reflection of the nutritional superiority of spring pasture over autumn pasture for maintenance and BCS gain (Mandok et al., 2014).

\section{Economic Modeling}

The milk price, gross revenue, operating expenses, operating profit, and cost of production calculated as part of the base economic model are presented in Table
3 and Supplemental Table S1 (https://doi.org/10.3168/ jds.2018-15911). The average milk price presented is the mean revenue from milk sales, including the premium earned for milk produced between the specified dates, divided by the mean annual amount of milk fat and protein produced by the treatment. As the profile of supply varied with PSC treatment, average milk price was less for the JUL treatment than for the JAN, APR, and OCT treatments, which did not differ from each other. In the base economic model (Table 3), gross revenue was greatest for the JUL treatment because of the greater milk production per hectare despite the lower average milk price. Operating expenses were not materially affected by calving date treatment, which means that the JUL treatment had a greater operating profit per hectare.

Assessment of risk to profit through the use of @Risk software (Palisade, 2017) was undertaken to provide 
Table 2. Effect of change in month of onset of calving in a seasonal calving system on lactation length; mean annual milk, fat, protein, and lactose production; average fat, protein, and lactose composition; BW and BCS 1 mo precalving and 1 wk postcalving; and calf birth weight

\begin{tabular}{|c|c|c|c|c|c|c|}
\hline \multirow[b]{2}{*}{ Item } & \multicolumn{4}{|c|}{ Onset of calving ${ }^{1}$} & \multirow[b]{2}{*}{$\mathrm{SED}^{2}$} & \multirow[b]{2}{*}{$P$-value } \\
\hline & JAN & $\mathrm{APR}$ & JUL & OCT & & \\
\hline Lactation length $(\mathrm{d})$ & 292 & 287 & 261 & 262 & 12.3 & 0.17 \\
\hline \multicolumn{7}{|l|}{ Annual production $(\mathrm{kg} / \mathrm{cow})$} \\
\hline Milk yield & 3,726 & 3,843 & 4,445 & 3,681 & 188.2 & 0.07 \\
\hline $4 \% \mathrm{FCM}$ & 4,057 & 4,236 & 4,878 & 4,002 & 218.9 & 0.08 \\
\hline Fat & 171 & 180 & 207 & 169 & 9.7 & 0.08 \\
\hline Protein & 128 & 134 & 154 & 123 & 6.5 & 0.06 \\
\hline Lactose & 179 & 186 & 215 & 177 & 10.5 & 0.09 \\
\hline \multicolumn{7}{|l|}{ Milk composition (\%) } \\
\hline Fat & 4.6 & 4.7 & 4.7 & 4.6 & 0.07 & 0.40 \\
\hline Protein & 3.5 & 3.5 & 3.5 & 3.3 & 0.06 & 0.27 \\
\hline Lactose & 4.8 & 4.9 & 4.9 & 4.8 & 0.04 & 0.60 \\
\hline \multicolumn{7}{|l|}{$\mathrm{BW}(\mathrm{kg})$} \\
\hline Precalving & $522^{\mathrm{a}}$ & $477^{\mathrm{b}}$ & $513^{\mathrm{a}}$ & $537^{\mathrm{a}}$ & 10.2 & $<0.05$ \\
\hline Postcalving & $465^{\mathrm{ac}}$ & $406^{\mathrm{b}}$ & $449^{\mathrm{c}}$ & $481^{\mathrm{a}}$ & 8.3 & $<0.01$ \\
\hline \multicolumn{7}{|l|}{ BCS } \\
\hline Precalving & 5.4 & 5.1 & 4.9 & 5.6 & 0.41 & 0.47 \\
\hline Postcalving & $4.6^{\mathrm{ab}}$ & $3.9^{\mathrm{b}}$ & $4.4^{\mathrm{ab}}$ & $5.1^{\mathrm{a}}$ & 0.20 & $<0.05$ \\
\hline Calf birth weight $(\mathrm{kg})$ & 38 & 37 & 37 & 39 & 0.8 & 0.18 \\
\hline
\end{tabular}

${ }^{\mathrm{a}-\mathrm{c}}$ Means with different superscripts differ significantly $(P<0.05)$.

${ }^{1} \mathrm{JAN}=$ planned calving date of January 10; APR = planned calving date of April 10; JUL = planned calving date of July 10; OCT = planned calving date of October 10.

${ }^{2}$ Standard error of the difference.

Table 3. Effect of change in month of onset of calving in a seasonal calving system and using fixed values ${ }^{1}$ for the input variables milk payment, ${ }^{2}$ meat payment, silage cost to buy, sell, and make, and urea price on the calculation of gross revenue, operating expenses, and operating profit per hectare and cost of production

\begin{tabular}{|c|c|c|c|c|}
\hline \multirow[b]{2}{*}{ Item } & \multicolumn{4}{|c|}{ Onset of calving ${ }^{3}$} \\
\hline & JAN & APR & JUL & OCT \\
\hline Milk payment (NZ\$) & 6.60 & 6.60 & 5.97 & 6.54 \\
\hline Fat and protein $(\mathrm{kg} / \mathrm{ha})$ & 928 & 972 & 1,118 & 905 \\
\hline \multicolumn{5}{|l|}{ Revenue (NZ\$) } \\
\hline Gross farm revenue & 6,572 & 6,823 & 7,090 & 6,268 \\
\hline \multicolumn{5}{|l|}{ Expenses $(\mathrm{NZ} \$)$} \\
\hline Total labor expenses & 1,165 & 1,158 & 1,164 & 1,162 \\
\hline Total stock expenses & 651 & 648 & 633 & 633 \\
\hline Total feed expenses & 345 & 214 & 223 & 332 \\
\hline Total other working expenses & 1,297 & 1,290 & 1,289 & 1,297 \\
\hline Total overhead & 660 & 662 & 644 & 647 \\
\hline Total dairy operating expenses (NZ\$) & 4,117 & 3,973 & 3,953 & 4,070 \\
\hline Dairy operating profit ${ }^{4}(\mathrm{NZ} \$)$ & 2,455 & 2,850 & 3,137 & 2,199 \\
\hline Expenses $(\mathrm{NZ} \$ / \mathrm{kg}$ of $\mathrm{FCM})$ & 0.36 & 0.34 & 0.29 & 0.36 \\
\hline Expenses $(\mathrm{NZ} \$ / \mathrm{kg}$ of fat and protein) & 4.44 & 4.09 & 3.54 & 4.50 \\
\hline
\end{tabular}

${ }^{1}$ Fixed values for the input variables are NZ $\$ 250 / \mathrm{t}$ of DM to purchase silage, NZ\$150/t of DM to sell silage, $\mathrm{NZ} \$ 100 / \mathrm{t}$ of DM to make silage, and $\mathrm{NZ} \$ 500 / \mathrm{t}$ of urea. Meat payment $(\mathrm{NZ} \$ / \mathrm{kg})$ varies by month: January $=$ $\$ 2.92$, February $=\$ 2.96$, March $=\$ 2.98$, April $=\$ 2.94$, May $=\$ 2.96$, June $=\$ 3.14$, July $=\$ 3.25$, August $=$ $\$ 3.34$, September $=\$ 3.35$, October $=\$ 3.19$, November $=\$ 3.08$, and December $=\$ 3.03$.

${ }^{2} \mathrm{NZ} \$ / \mathrm{kg}$ of fat and protein supplied. It differs for each treatment because the value of protein differs from the value of fat in component-pricing markets. Therefore, if the change in planned calving date affects protein or fat percentages, it will affect milk price.

${ }^{3} \mathrm{JAN}=$ planned calving date of January 10; APR = planned calving date of April 10; JUL = planned calving date of July 10; OCT = planned calving date of October 10.

${ }^{4}$ Gross farm revenue less the operating expenses. 

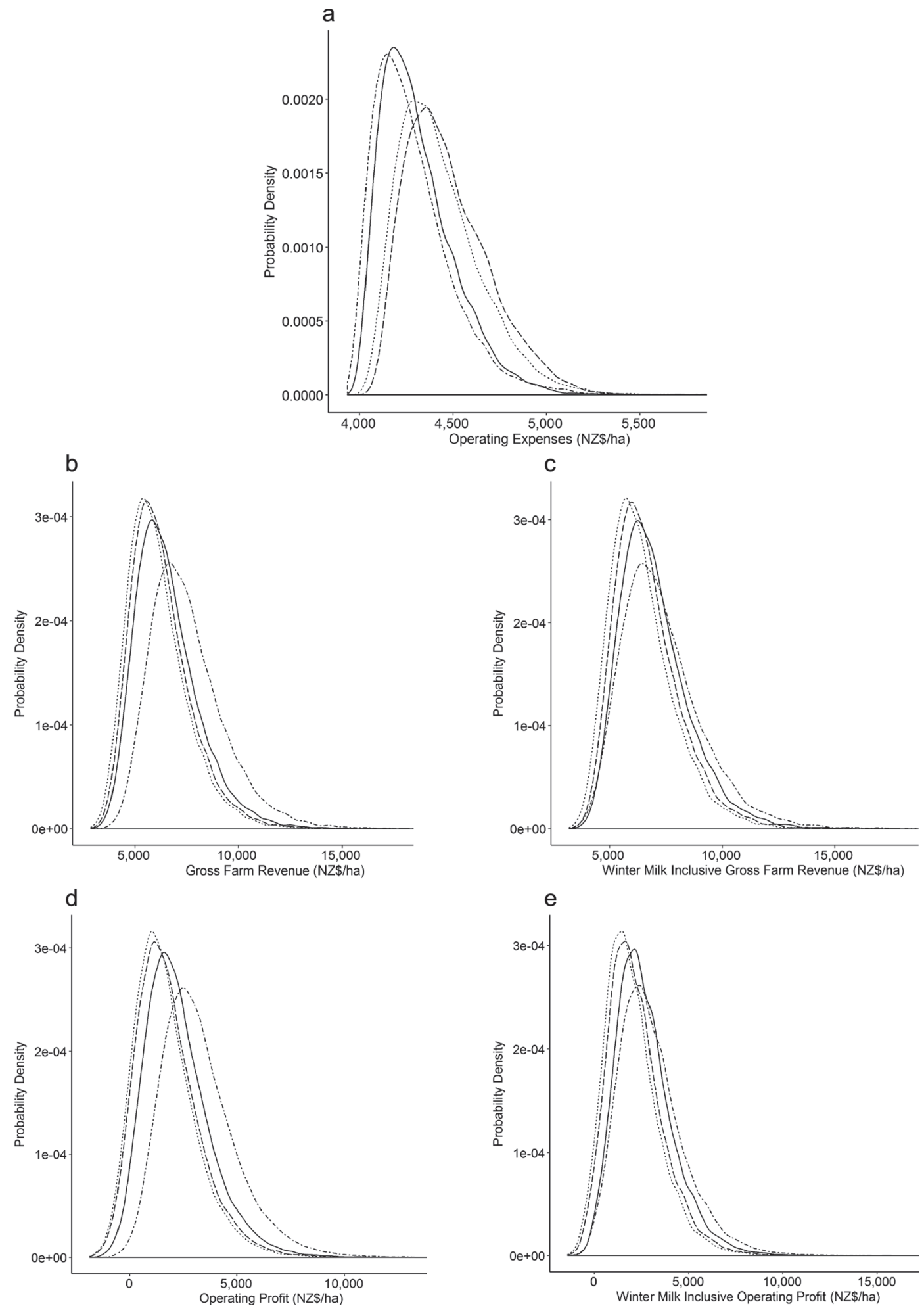

Figure 3. Probability distributions of model output variables: operating expenses (a; NZ $\$ /$ ha), gross farm revenue (NZ\$/ha) with (b) and without (c) a premium for milk produced outside the normal season (i.e., winter milk), and operating profit (NZ $\$ /$ ha) with (d) and without (e)

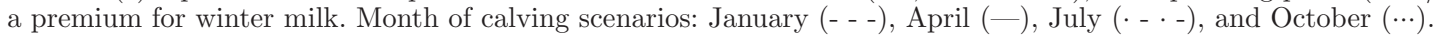


Table 4. Effect of change in month of onset of calving in a seasonal calving system and stochastic input variable ${ }^{1}$ on revenue items, expense items, and the output variables gross farm revenue, operating expenses, and operating profit modeled under 2 scenarios using @Risk software (Palisade, 2017)

\begin{tabular}{|c|c|c|c|c|c|}
\hline \multirow[b]{2}{*}{ Item } & \multirow[b]{2}{*}{ Scenario $^{2}$} & \multicolumn{4}{|c|}{ Onset of calving $^{3}$} \\
\hline & & JAN & APR & JUL & OCT \\
\hline \multicolumn{6}{|l|}{ Revenue (NZ\$/ha) } \\
\hline Net milk sales/ha & A & 5,718 & 5,990 & 6,889 & 5,578 \\
\hline Net stock income & NA & 436 & 408 & 398 & 350 \\
\hline Surplus silage sales ${ }^{4}$ & NA & 0 & 23 & 136 & 5 \\
\hline \multicolumn{6}{|l|}{ Expenses (NZ\$/ha) } \\
\hline Supplements purchased ${ }^{4}$ & NA & 132 & 0 & 0 & 0 \\
\hline Silage conservation ${ }^{4}$ & NA & 233 & 174 & 245 & 297 \\
\hline Nitrogen & NA & 244 & 244 & 244 & 244 \\
\hline \multirow[t]{3}{*}{ Gross farm revenue $(\mathrm{NZ} \$ /$ ha $)$} & $\mathrm{A}$ & 6,153 & 6,421 & 7,424 & 5,932 \\
\hline & B & 6,562 & 6,849 & 7,211 & 6,276 \\
\hline & $\pm \mathrm{SD}$ & 1,479 & 1,564 & 1,804 & 1,459 \\
\hline \multirow[t]{2}{*}{ Operating expenses $(\mathrm{NZ} \$ / \mathrm{ha})$} & NA & 4,304 & 4,099 & 4,142 & 4,202 \\
\hline & $\pm \mathrm{SD}$ & 224 & 199 & 211 & 223 \\
\hline \multirow[t]{3}{*}{ Operating profit $(\mathrm{NZ} \$ / \mathrm{ha})$} & $\mathrm{A}$ & 1,850 & 2,322 & 3,282 & 1,730 \\
\hline & B & 2,258 & 2,749 & 3,069 & 2,079 \\
\hline & $\pm \mathrm{SD}$ & 1,501 & 1,556 & 1,769 & 1,458 \\
\hline
\end{tabular}

${ }^{1}$ Fitted distribution means (presented in Figure 3): meat price $=\mathrm{NZ} \$ 3.09 / \mathrm{kg}$; urea price $=\mathrm{NZ} \$ 711 / \mathrm{t}$; silage purchase $=\mathrm{NZ} \$ 287 / \mathrm{t}$ of DM; silage sale $=\mathrm{NZ} \$ 187 / \mathrm{t}$ of DM; making silage $=\mathrm{NZ} \$ 137 / \mathrm{t}$ of DM.

${ }^{2}$ Scenario $\mathrm{A}=$ no premium included in milk payment variable $(\mathrm{NZ} \$ 6.16 / \mathrm{kg}$ of fat and protein for JAN, APR, JUL, and OCT treatments). Scenario B = premium for milk supplied during May 16 to July 15 included in milk payment variable $(\mathrm{NZ} \$ 6.60, \mathrm{NZ} \$ 6.60, \mathrm{NZ} \$ 5.97$, and $\mathrm{NZ} \$ 6.54 / \mathrm{kg}$ of fat and protein for JAN, APR, JUL, and OCT treatments, respectively). NA = not applicable.

${ }^{3} \mathrm{JAN}=$ planned calving date of January 10; APR = planned calving date of April 10; JUL = planned calving date of July 10; OCT = planned calving date of October 10.

${ }^{4}$ Amount of silage purchased, sold, and made based on modeled amount of pasture growth due to annual growth variation during the trial.

insight into how variation in milk price and key input parameters affects profitability metrics. This method yields a distribution for each model output, conditional on the joint distribution of all input data. Individual distributions for each input variable are presented in Figure 1. The output variables were modeled under 2 scenarios: (A) without a premium for milk produced out of season (i.e., between May 15 and July 15) and (B) with a commercially realistic premium included (Chikazhe et al., 2017). Distributions of the output variables of the model generated with Monte Carlo simulation using @Risk (Palisade, 2017) are presented in Figure 3.

Gross farm revenue per hectare calculated using a standardized milk payment of $\$ 6.16 / \mathrm{kg}$ of fat and protein (scenario A) was $\$ 6,153, \$ 6,421, \$ 7,424$, and $\$ 5,932$ on average for the JAN, APR, JUL, and OCT calving treatments, respectively (Figure 3). When calculated using a milk price that includes an adjustment for a premium earned for winter milk produced (scenario B; calculations in Supplemental Table S4, https://doi .org/10.3168/jds.2018-15911; Chikazhe et al., 2017), the mean gross farm revenue per hectare was $\$ 6,562$, $\$ 6,849, \$ 7,211$, and $\$ 6,276$ for the JAN, APR, JUL, and OCT treatments, respectively (Figure 3 ). Therefore, the adjustment for winter milk premium earned an extra $\$ 409, \$ 428$, and $\$ 344 /$ ha on average for the JAN, APR, and OCT treatments, respectively. However, the gross farm revenue for the JUL treatment decreased by $\$ 213$ / ha under the adjusted payment system because of a downward adjustment on milk price for milk produced during peak supply (Chikazhe et al., 2017). Compared with the greater milk fat and protein payment received by the other 3 treatments, the JUL calving treatment received the lowest average milk price of $\$ 5.97 / \mathrm{kg}$ of fat and protein. Mean operating expenses per hectare were not greatly affected by calving date treatment (Table 4), with the small differences in the cost of making silage and a requirement to purchase a small amount of supplement for the JAN treatment to ensure the feed budget was balanced. Operating profit per hectare was greatest in the JUL calving treatment regardless of whether a winter milk premium was included.

A CDF is presented without (Figure 4a) and with (Figure $4 \mathrm{~b}$ ) the inclusion of a milk price premium for out-of-season milk. The CDF is useful in decisionmaking contexts because it contains all the information on the output distribution, showing the likelihood of the potential outcomes. By comparing the CDF, the stochastically dominant set can be determined. If one 
CDF lies to the right of another over the entire probability interval, first-degree stochastic dominance of the risk outcome (on the right) over another is implied (Hardaker et al., 2015).

When the winter milk premium is excluded, the JUL calving treatment exhibited stochastic dominance over the other 3 treatments; these results mean that designing a winter PSC, such that the profile of pasture growth is aligned with herd feed demand, is
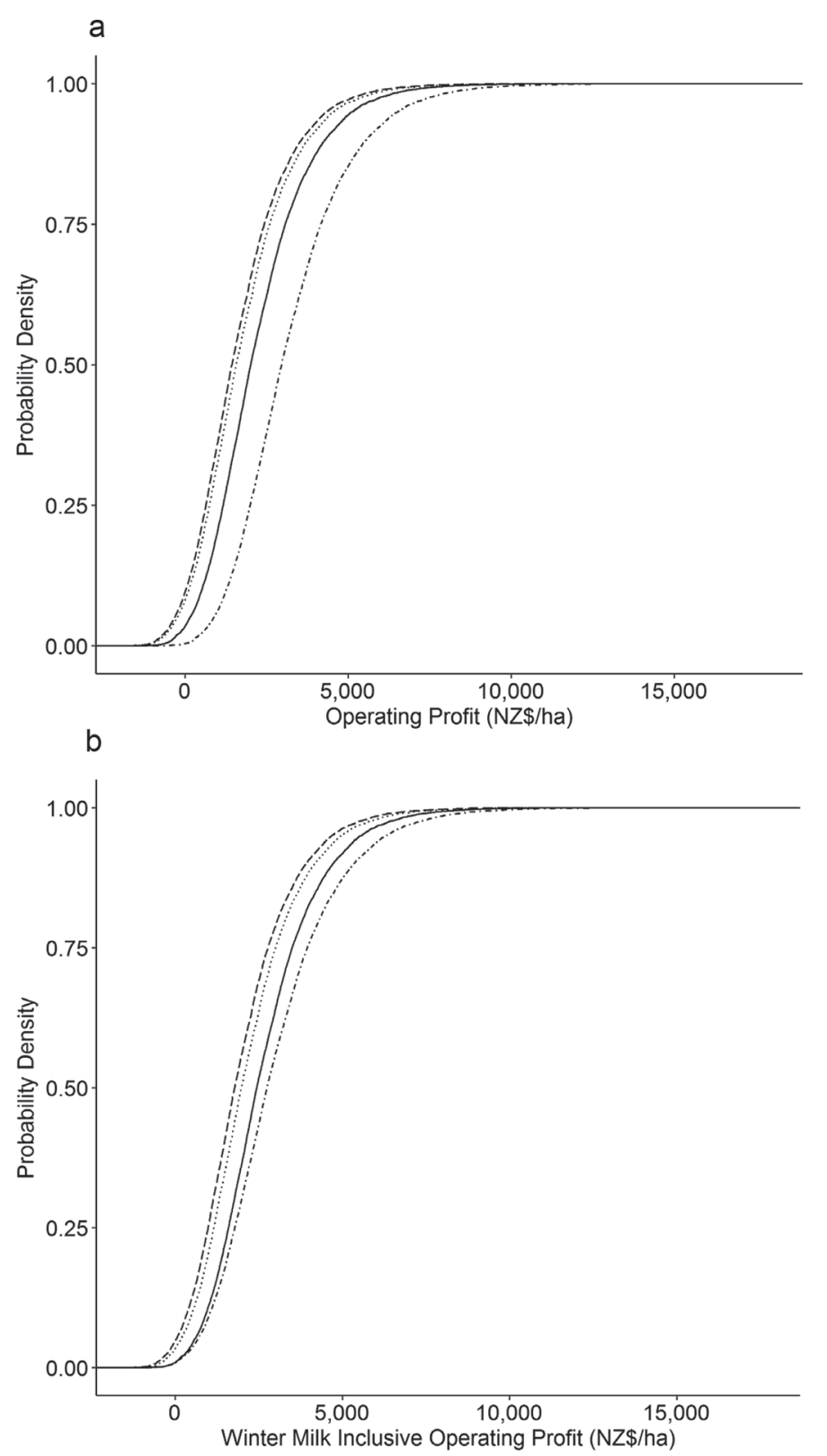

Figure 4. Cumulative density function for the effect of change in month of onset of calving on the operating profit (NZ\$/ha) without premium payment for winter milk supplied (a) and with premium payment (b). January (- - ) , April (-), July ( - - -), and October $(\cdots)$. more likely to be profitable than calving in January, April, or October. In addition, the APR treatment was stochastically dominant over the JAN and OCT treatments. With the inclusion of the winter milk premium, the JUL treatment remained stochastically dominant over the other 3 treatments, and the APR treatment remained stochastically dominant over the JAN and OCT treatments. Therefore, even with inclusion of the winter milk premium in the milk payment input variable, the decision to calve in mid to late winter in a temperate climate zone is less risky than the other 3 options for the outcome of operating profit per hectare. Furthermore, we believe that our economic modeling is conservative, with anecdotal evidence of increased repairs and maintenance expenses for machinery and lameness in grazing herds producing winter milk. It is likely, therefore, that the probability of stochastic dominance of a mid- to late-winter calving treatment group is greater than has been portrayed here.

\section{CONCLUSIONS}

The comparison of farmlets differing only in their PSC presented us with a unique opportunity to use a quantitative case study approach to evaluate the economics of calving season in a temperate pasture-based system. The analyses undertaken indicate that a PSC in winter increases the proportion of fresh pasture in the diet of the lactating cow; this tended to increase milk production relative to the other calving dates, which increased milk revenue. Operating expenses were not materially affected by calving date treatment. Therefore, operating profit was greater in the JUL calving treatment. Furthermore, when the variability in annual pasture growth, input prices, and milk prices was considered, the JUL calving treatment was consistently the most profitable, followed by the APR calving treatment, even following the inclusion of a commercially realistic winter milk price premium.

\section{ACKNOWLEDGMENTS}

The authors acknowledge the help afforded them by the No. 2 Dairy staff (DairyNZ Inc., Hamilton, New Zealand), A. Duker, and L. Bowler as well as the statistical expertise of B. Dow (DairyNZ Inc.). This work was funded by New Zealand Dairy Farmers through DairyNZ Inc.

\section{REFERENCES}

Chikazhe, T. L., K. A. Mashlan, P. C. Beukes, C. B. Glassey, J. Haultain, and M. B. Neal. 2017. The implications of winter milk premiums for sustainable profitability of dairy systems. J. N. Z. Grasslands 48:49-51. 
Cliff, S. C., G. R. Morris, I. S. Hook, and K. L. MacMillan. 1995. Calving patterns in dairy heifers following single "set-time" inseminations and re-synchrony preceding second inseminations. Proc. N.Z. Soc. Anim. Prod. 55:70-71.

Davis, J., and A. Kirk. 1984. Economic aspects of changing the seasonality of milk production and pricing. Irish J. Agric. Econ. Rural Sociol. 10:97-102.

Dillon, P., S. Crosse, B. O'Brien, and R. W. Mayes. 2002. The effect of forage type and level of concentrate supplementation on the performance of spring-calving dairy cows in early lactation. Grass Forage Sci. 57:212-223. https://doi.org/10.1046/j.1365-2494.2002 .00319.x.

Dillon, P., S. Crosse, G. Stakelum, and F. Flynn. 1995. The effect of calving date and stocking rate on the performance of springcalving dairy cows. Grass Forage Sci. 50:286-299. https://doi.org/ 10.1111/j.1365-2494.1995.tb02324.x.

Dillon, P., J. R. Roche, L. Shalloo, and B. Horan. 2005. Optimising financial returns from grazing in temperate pastures. Pages 131-147 in Utilisation of Grazed Grass in Temperate Animal Systems. Proceedings of a satellite workshop of the XXth International Grassland Congress, Cork, Ireland.

Funston, R. N., E. E. Grings, A. J. Roberts, and B. T. Tibbitts. 2016. Invited review: Choosing a calving date. Prof. Anim. Sci. 32:145-153. https://doi.org/10.15232/pas.2015-01463.

García, S. C., and C. W. Holmes. 2005. Seasonality of calving in pasture-based dairy systems: Its effects on herbage production, utilisation and dry matter intake. Aust. J. Exp. Agric. 45:1-9. https:/ /doi.org/10.1071/EA00110.

García, S. C., C. W. Holmes, A. MacDonald, M. Lundman, J. Lundman, and R. Pacheco-Navarro. 2000. Comparative efficiency of autumn and spring calving for pasture-based dairy systems. Asianaustralas. J. Anim. Sci. 13:533-537.

Hardaker, J. B., G. Lien, J. R. Anderson, and R. B. M. Huirne. 2015. Coping with Risk in Agriculture. 3rd ed. Applied Decision Analysis. CABI, Wallingford, UK.

Keane, M. 2010. Potential Investment Costs in Milk Processing and Transport to 2020. Irish Creamery Milk Suppliers Association, Limerick, Ireland.

Macdonald, K. A., D. Beca, J. W. Penno, J. A. S. Lancaster, and J. R. Roche. 2011. Short Communication: Effect of stocking rate on the economics of pasture-based dairy farms. J. Dairy Sci. 94:25812586 .

Macdonald, K. A., and J. W. Penno. 1998. Management decision rules to optimise milksolids production on dairy farms. Pages 132-135 in Proc. 58th Conf. NZ Soc. Anim. Prod. Palmerston North, NZ.

Macdonald, K. A., J. W. Penno, J. A. S. Lancaster, A. M. Bryant, J. M. Kidd, and J. R. Roche. 2017. Production and economic responses to intensification of pasture-based dairy production systems. J. Dairy Sci. 100:6602-6619.

Macdonald, K. A., J. W. Penno, J. A. S. Lancaster, and J. R. Roche. 2008. Effect of stocking rate on pasture production, milk produc- tion, and reproduction of dairy cows in pasture-based systems. J. Dairy Sci. 91:2151-2163. https://doi.org/10.3168/jds.2007-0630.

Mandok, K. M., J. K. Kay, S. L. Greenwood, J. P. McNamara, M. Crookenden, R. White, S. Shields, G. R. Edwards, and J. R. Roche. 2014. Efficiency of use of metabolizable energy for body weight gain in pasture-based, nonlactating dairy cows. J. Dairy Sci. 97:4639-4648. https://doi.org/10.3168/jds.2013-6912.

McCarthy, B., K. M. Pierce, L. Delaby, A. Brennan, and B. Horan. 2012. The effect of stocking rate and calving date on reproductive performance, body state, and metabolic and health parameters of Holstein-Friesian dairy cows. J. Dairy Sci. 95:1337-1348. https:// doi.org/10.3168/jds.2011-4783.

Neal, M., and S. Cooper. 2016. Modelling the risk, return and resiliency of future dairy farm systems. Pages 1-25 in Proc. Australian Agricultural and Resource Economics Society, Canberra, Australia.

O'Donovan, M., P. Dillon, M. Rath, and G. Stakelum. 2002. A comparison of four methods of herbage mass estimation. Ir. J. Agric. Food Res. 41:17-27.

Palisade. 2017. @Risk for Risk Analysis. Accessed Aug. 21, 2018 https://www.palisade.com/risk/.

R Core Team. 2013. R: A Language and Environment for Statistical Computing. R Foundation for Statistical Computing, Vienna, Austria.

Roche, J. R. 2017. Nutrition Management of Grazing Dairy Cattle. Vol. 3. Burleigh Dodds Science Publishing, Cambridge, UK.

Roche, J. R., P. G. Dillon, C. R. Stockdale, L. H. Baumgard, and M. J. VanBaale. 2004. Relationships among international body condition scoring systems. J. Dairy Sci. 87:3076-3079. https://doi.org/ 10.3168/jds.S0022-0302(04)73441-4.

Roche, J. R., N. C. Friggens, J. K. Kay, M. W. Fisher, K. J. Stafford, and D. P. Berry. 2009a. Invited review: Body condition score and its association with dairy cow productivity, health, and welfare. J. Dairy Sci. 92:5769-5801. https://doi.org/10.3168/jds.2009-2431.

Roche, J. R., E. S. Kolver, and J. K. Kay. 2005. Influence of precalving feed allowance on periparturient metabolic and hormonal responses and milk production in grazing dairy cows. J. Dairy Sci 88:677-689. https://doi.org/10.3168/jds.S0022-0302(05)72732-6.

Roche, J. R., L. R. Turner, J. M. Lee, D. C. Edmeades, D. J. Donaghy, K. A. Macdonald, J. W. Penno, and D. P. Berry. 2009b. Weather, herbage quality and milk production in pastoral systems. 2. Temporal patterns and intra-relationships in herbage quality and mineral concentration parameters. Anim. Prod. Sci. 49:200-210. https: //doi.org/10.1071/EA07310.

Roche, J. R. S. P. Washburn, D. P. Berry, D. J. Donaghy, and B. Horan. 2017. Seasonal pasture-based dairy production systems. Pages 99-114 in Large Dairy Herd Management. 3rd ed. D. Beede, ed. American Dairy Science Association, Champaign, IL. 